\title{
Spatial variability of shallow groundwater level in the Northern Kathmandu Valley
}

\author{
*Manish Shrestha ${ }^{1}$ and Naresh Kazi Tamrakar² \\ ${ }^{1}$ Shivam Cement Pvt. Ltd., Hetauda, Makwaanpur District, Nepal \\ ${ }^{2}$ Central Department of Geology, Tribhuvan University, Kirtipur, Kathmandu, Nepal \\ *Corresponding author: angerousmanish@gmail.com
}

\begin{abstract}
Groundwater is the water which is present in pore spaces and in the fractures of the geological materials beneath earth surface. Water is incompressible substance and presence of small amount of water in geological material modifies the behavior of geological material under stresses. Determination of engineering behavior of the geological material is almost impossible skipping the role of water. The objective of this study was to map and evaluate shallow groundwater level of the northern Kathmandu Valley covering main rivers such as the Bagmati River, Bishnumati River, Dhobi Khola and the Manahara Khola. These rivers flow from the North to the South across the sand rich sediment zone. Static groundwater levels of 239 wells were measured from different locations of the study area in April/March 2017 (Dry Season) and in August 2017 (Wet Season). Shallow groundwater level was measured from soil surface to water level using well water depth logger (Qin and $\mathrm{Li}, 1998$ ). The result showed that groundwater level ranged from $0.6 \mathrm{~m}$ to 12.5 $\mathrm{m}$ in dry season and $0.1 \mathrm{~m}$ to $13 \mathrm{~m}$ in wet season. The groundwater level increased by average of $34.68 \%(\mathrm{n}=235)$ as compared to that in dry season. Increase in the groundwater level suggests recharge of groundwater in wet season of the study area. The flow pattern of groundwater levels from the study shows flow of shallow groundwater towards the major rivers of that particular river watershed. As a consequence, seepage flow and piping erosion is likely along the riverbank slopes. Increase in recharge of groundwater during wet season exhibits that the northern region of the Kathmandu Valley is potential for groundwater recharge and can be used to manage water for the dry period.
\end{abstract}

Keywords: Shallow wells, Northern Kathmandu Valley, Dry season, Wet season, Water level

Paper Received: 28 Jan 2018

Paper Accepted: 8 March 2018

\section{INTRODUCTION}

Shallow groundwater generally refers to the groundwater which is found below ground surface up to depth of $15 \mathrm{~m}$. This water is present in the pore spaces of the geological materials or on the fractures of rocks. The major sources of water in ancient period in Kathmandu valley used to be stone spouts, dug wells and the water direct from the river and ponds. But with the increasing population, urbanization such sources got polluted and even lead to drying of stone spouts and wells which eventually aroused the problem of scarcity of clean and safe water. Fluctuation in water level is highly dependent on the amount of use of groundwater, surrounding landuse pattern and availability of recharge area.

Many researchers have worked on the groundwater of the Kathmandu Valley (Sharma and Singh,1966; JICA, 1990; Dixit and Upadhya, 2005). JICA (1990) conducted a research on groundwater management project of the Kathmandu Valley. Dixit and Upadhya (2005) studied the groundwater condition of the Kathmandu valley and identified the avenues for groundwater potential to meet the municipal water supply need. However, there is lack of concrete approach on the study on condition of shallow wells and change in level of groundwater level during the dry and the wet periods. There is lack of detail information about shallow wells, aquifer and hydraulic dynamics of the Kathmandu Valley. This study aims to clarify groundwater condition of the Kathmandu Valley based on two seasons primarily focusing on the change on groundwater level of 239 wells that are located in the study area. The main objective of this study was to map and evaluate the shallow groundwater level of the study area of dry (pre-monsoon) and wet (monsoon) season.

The study area lies in the northern part of the Kathmandu Valley covering the major areas of the Kathmandu District and some area of the Bhaktapur District, incorporating the major drainage system of the valleys like Bagmati River, Bishnumati River, Dhobi Khola and the Manahara Khola (Fig. 1).

\section{METHODOLOGY}

Fieldwork was carried out in the month of March/April of year 2017 for collection of data of dry season and collection of wet season was carried out on August month of the same year and altogether data of 239 wells were collected from different locations of the Northern Kathmandu Valley (Fig. 1). A water-depth logger was used to measure the static water level from the wells. The water level was measured from the ground soil surface to water level (Qin and Li, 1998). After completion of data collection, data were processed to create different maps to draw result and conclusions. 


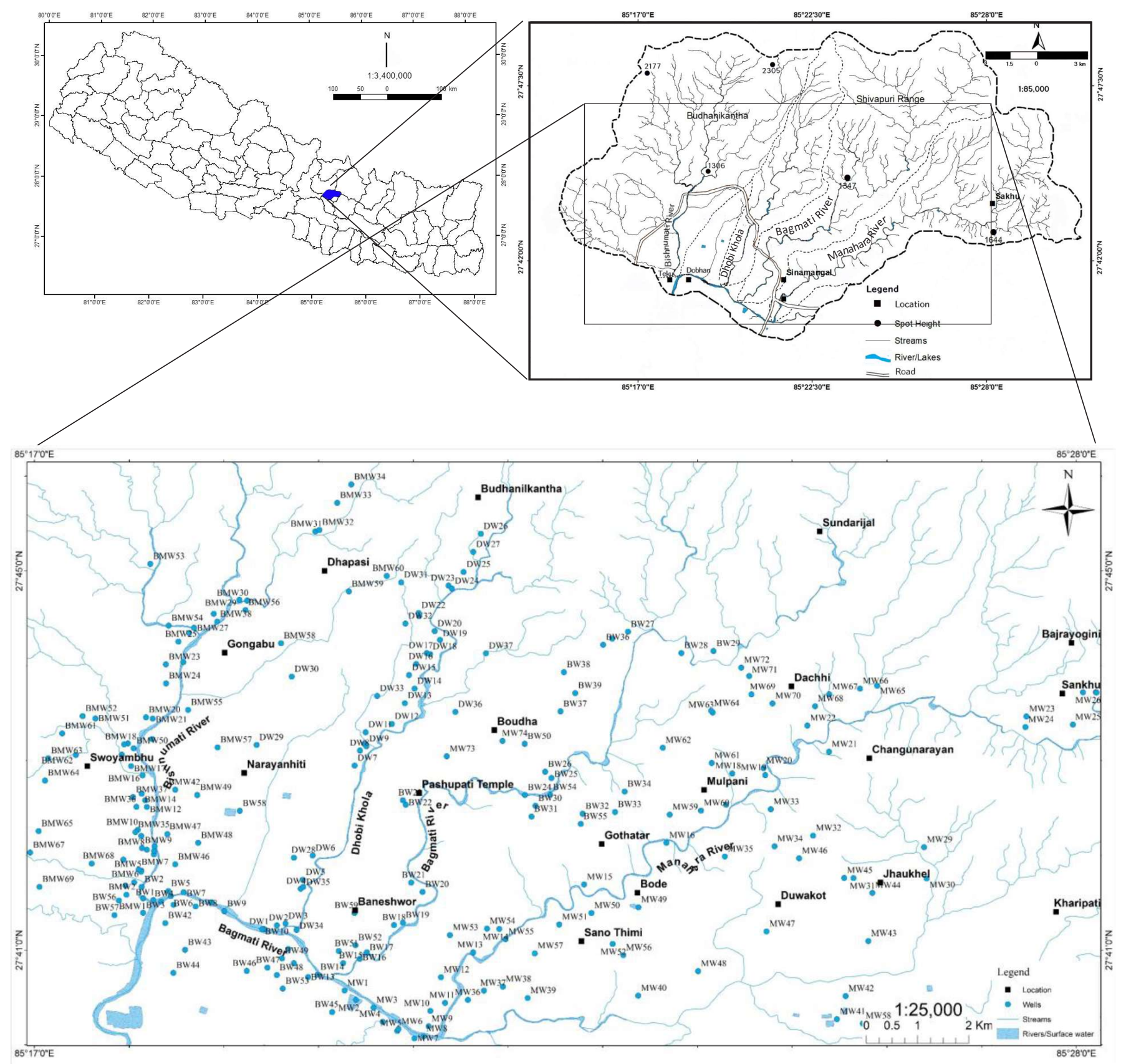

Fig. 1: Location and well distribution map of the study area

\section{GEOLOGY OF STUDY AREA}

Various studies and researches carried out in Kathmandu Valley defined their own stratigraphic units by their authors. However, this study is based on the Environmental and Engineering geological map prepared by DMG (1998) in cooperation of BGR, DOI and GMBH. Geology of study area is divided into three groups with different formations (Fig. 2). They are: (a) Quaternary Sediments, (b) Plio-Pleistocene Sediments and (c) Pre-cambrian Devonian Hard rock.

\section{Quaternary Sediments}

Quaternary Sediments includes recent unconsolidated sediments and includes following units:

\section{Recent Alluvial Soil}

This is recent deposit by flood plain and lower alluvial terraces. Sands and gravel deposits up to boulder size are found in northern part while clay, sand and fine gravel are common in southern and central part. These are high potential of groundwater with periodic change of shallow groundwater table. 




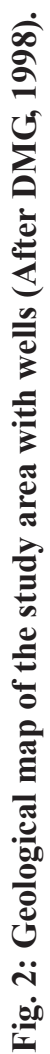




\section{Alluvial Fan Deposits}

Gravel, sandy gravel and silt are main composition of this deposit. The thickness of deposit increases toward the centre of fan. They are highly potential for shallow groundwater, and have high infiltration rate of surface water. They may have presence of perched water.

\section{Plio-Pleistocene Deposits}

These deposits are slightly consolidated of age from Pliocene to Pleistocene. These deposits are divided into following units:

\section{Tokha Formation}

The Tokha Formation is composed of dark gray clay and brownish gray sand and poorly sorted subangular to rounded sandy gravels of thickness $200 \mathrm{~m}$ or more. They have moderate to high groundwater potential however groundwater table is shallow to moderately deep.

\section{Gokarna Formation}

The Gokarna Formation consists of light to brownish gray, fine laminated and poorly graded silty sand with intercalation of clay of variable thickness. The total thickness of the formation is up to $300 \mathrm{~m}$. This formation has medium groundwater potential.

\section{Chapagaon Formation}

The Chapagaon Formation consists of subrounded to rounded silty sandy gravel with boulder bed, clays silt and silty sand. The total thickness of the formation is up to $110 \mathrm{~m}$, and has high groundwater potential with moderately deep groundwater level.

\section{Kalimati Formation}

The Kalimati Formation consists of gray to dark silty clay and clayey silt at some places calcareous nature is also found. The thickness is up to $450 \mathrm{~m}$. This formation generally has low groundwater potential and acts like an aquitard with low permeability.

\section{Lukundol Formation}

The Lukundol Formation comprises semi-consolidated sandy, clayey silt interbedded with gravel and clayey sand, peat and lignite. The total thickness is up to $80 \mathrm{~m}$ of this formation. It has low groundwater potential with deep groundwater level.

\section{Precambrian to Devonian hard rock}

The bedrocks found in the Kathmandu Valley range from Precambrian to Devonian age.

\section{Chandragiri Formation}

The Chandragiri Formation consists of pale bluish gray to brown, medium to thick bedded massive finely crystalline limestone with thickness of $2000 \mathrm{~m}$. The limestone has good groundwater potential.

\section{Sopyang Formation}

The Sopyang Formation consists of dark, thinly bedded calcareous slate with thickness of up to $200 \mathrm{~m}$. It has low groundwater potential with low to medium permeability.

\section{Tistung Formation}

The Tistung Formation comprises greenish grey to brown fine-grained phyllite and slate interbedded with metasandstone. The total thickness of this formation is up to $3000 \mathrm{~m}$. This formation possesses moderate groundwater potential in metasandstone present.

\section{Kulikhani Formation}

The Kulikhani Formation consists of greenish grey biotite schist with schistose quartzite. The thickness of this formation is up to $2000 \mathrm{~m}$. It has low groundwater potential with low to medium permeability.

\section{Sheopuri Gneiss}

The Sheopuri Gneiss shows different lithological characteristics. In the southern part, mica gneiss and biotite schist are common while in the northern part medium- to coarsegrained muscovite, granite with intercalation of mica gneiss and dark biotite schist are common. This formation has low to moderate groundwater potential.

\section{RESULTS AND DISCUSSIONS}

Water level measurement is the basic task in groundwater hydrogeology. Static water level of wells was measured of the study area in both dry and wet season. The data of water level of wells of two different seasons area given in the Table 1. The water level was used to find out the groundwater flow direction or flow pattern. The flow direction of groundwater is slope dependent and is necessary for quantitative analysis of recharge and discharge of the area. The water table map above mean sea level (Figs. 3 and 4) based upon depth of water level shows that general flow is towards southern part of the study area from periphery and follows the surface drainage system ultimately joining the Bagmati River. The same type of flow pattern is also observed in wet season. The maximum depth of water level was $12.5 \mathrm{~m}$ in Well Id BMW57 and minimum depth of water level was $0.6 \mathrm{~m}$ of Well Id MW25 in dry season. While in wet season maximum depth of water level was $13 \mathrm{~m}$ in Well Id BW61 and minimum depth of water level was $0.1 \mathrm{~m}$ in Well Id MW2, MW27, and DW4. 


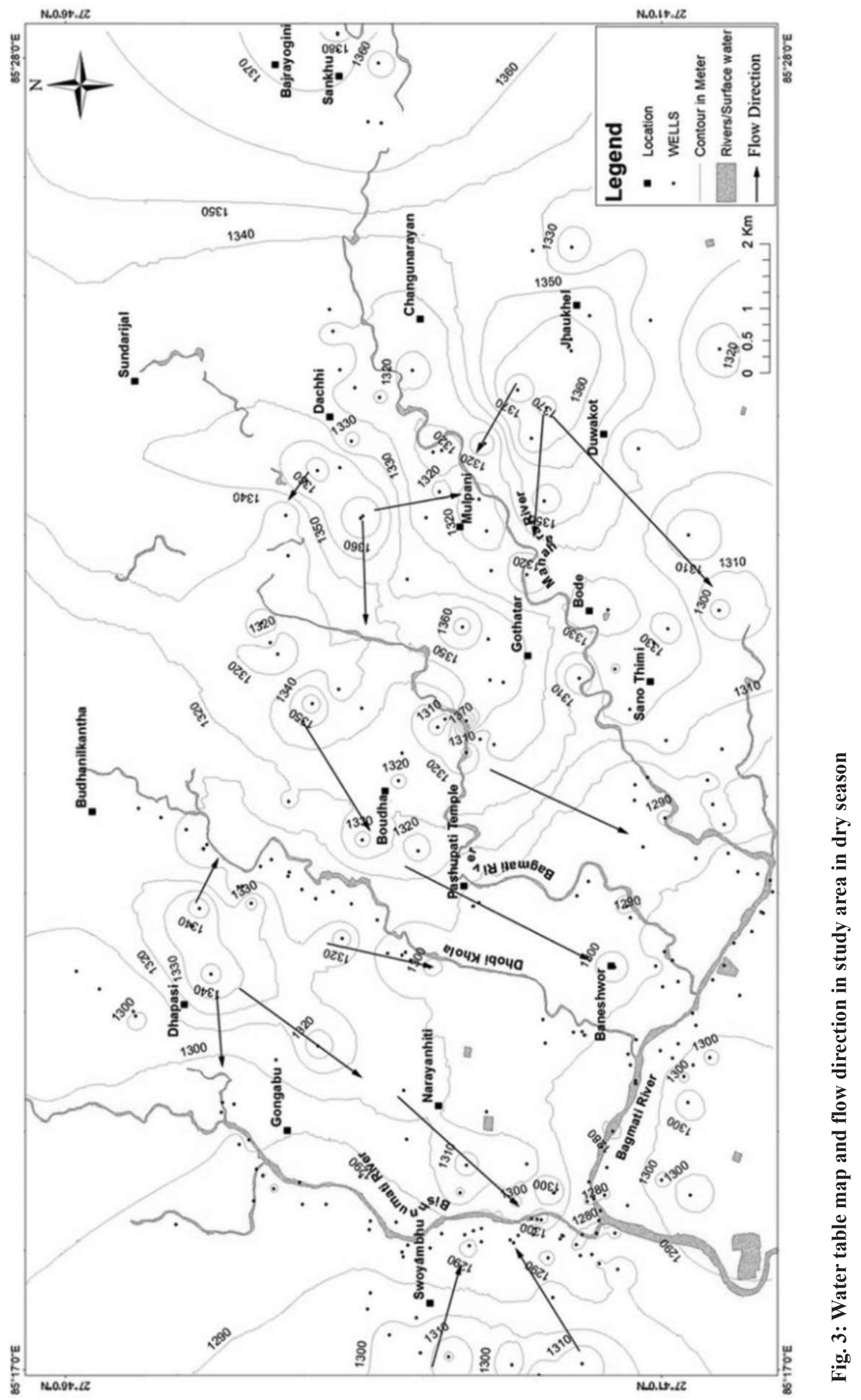




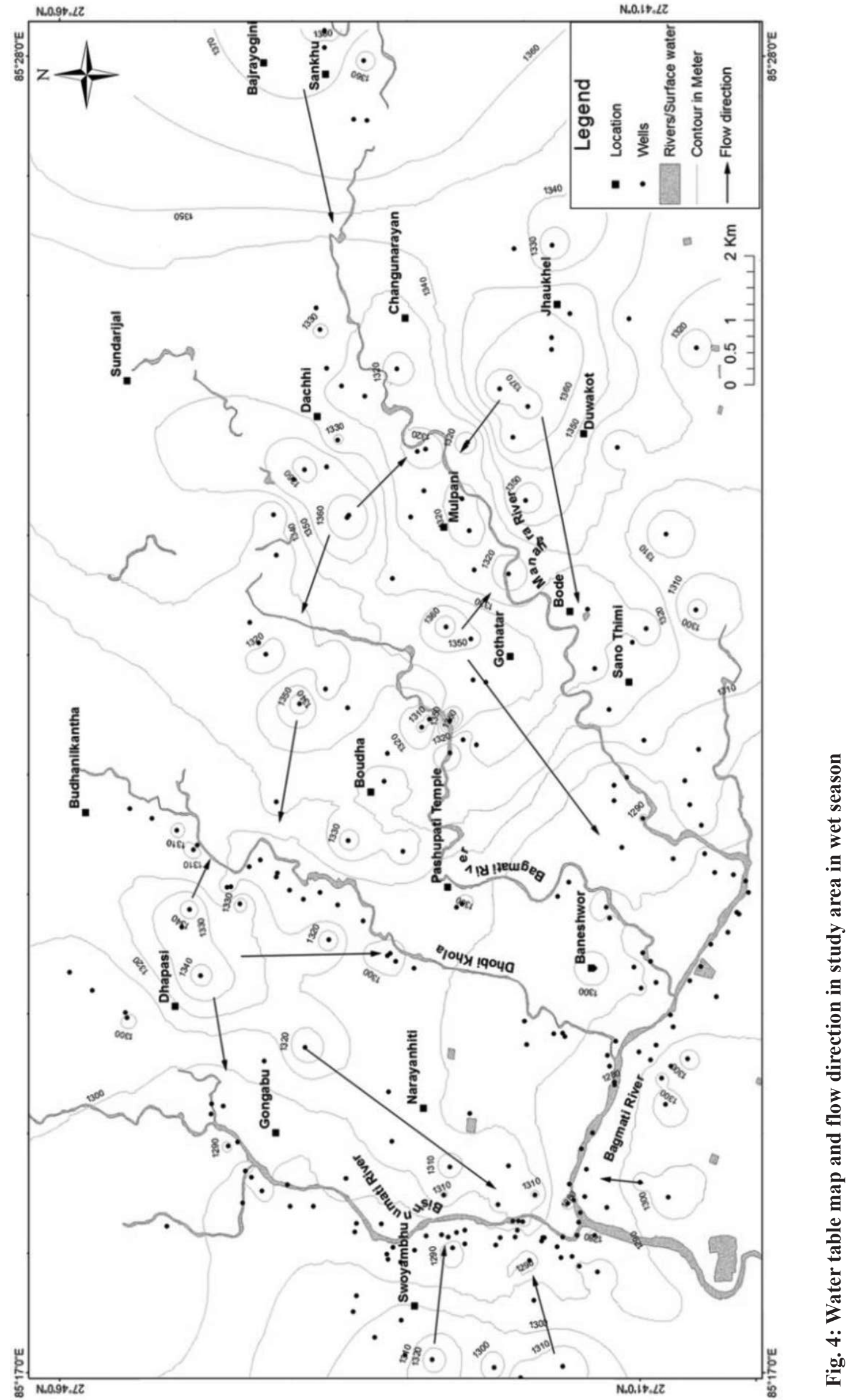


Table 1: Data of water level collected from the field

\begin{tabular}{|c|c|c|c|c|c|c|c|c|c|c|c|}
\hline $\begin{array}{l}\text { S. } \\
\text { No }\end{array}$ & Well ID & $\begin{array}{c}\text { Shallow } \\
\text { ground } \\
\text { water level } \\
\text { of dry } \\
\text { season (LD) }\end{array}$ & $\begin{array}{c}\text { Shallow } \\
\text { ground } \\
\text { Water level } \\
\text { of wet } \\
\text { season (LW) }\end{array}$ & $\begin{array}{l}\text { S. } \\
\text { No }\end{array}$ & Well ID & $\begin{array}{c}\text { Shallow } \\
\text { ground water } \\
\text { level } \\
\text { of dry season } \\
\text { (LD) }\end{array}$ & $\begin{array}{c}\text { Shallow } \\
\text { ground } \\
\text { Water level } \\
\text { of wet } \\
\text { season (LW) }\end{array}$ & $\begin{array}{l}\text { S. } \\
\text { No }\end{array}$ & Well ID & $\begin{array}{c}\text { Shallow } \\
\text { ground } \\
\text { water level } \\
\text { of dry } \\
\text { season (LD) }\end{array}$ & $\begin{array}{c}\text { Shallow } \\
\text { ground } \\
\text { Water level } \\
\text { of wet } \\
\text { season (LW) }\end{array}$ \\
\hline 1 & BW1 & 2.3 & 0.65 & 41 & BW41 & 4.6 & 1.8 & 81 & BMW20 & 4.9 & 0.4 \\
\hline 2 & BW2 & 0.6 & 0.7 & 42 & BW42 & 6.8 & 5 & 82 & BMW21 & 5 & 1.3 \\
\hline 3 & BW3 & 2.1 & 2.2 & 43 & BW43 & 2.9 & 2.3 & 83 & BMW22 & 2.25 & 1.6 \\
\hline 4 & BW4 & 1.2 & 1.2 & 44 & BW44 & 3.9 & 1.2 & 84 & BMW23 & 2.2 & 1 \\
\hline 5 & BW5 & 1.35 & 3 & 45 & BW45 & 2.6 & 0.7 & 85 & BMW24 & 6.8 & 2 \\
\hline 6 & BW6 & 1.85 & 1 & 46 & BW46 & 1.3 & 0.5 & 86 & BMW25 & 2.65 & 1.7 \\
\hline 7 & BW7 & 3.2 & 3.5 & 47 & BW47 & 5.4 & 4.3 & 87 & BMW26 & 2.7 & 1.7 \\
\hline 8 & BW8 & 2 & 0.9 & 48 & BW48 & 1.1 & 0.5 & 88 & BMW27 & 4.2 & 2.7 \\
\hline 9 & BW9 & 3 & 1.8 & 49 & BW49 & 3.6 & 0.5 & 89 & BMW28 & 3.6 & 1.4 \\
\hline 10 & BW10 & 2.6 & 3.4 & 50 & BW50 & 3.8 & 2.6 & 90 & BMW29 & 2.4 & 1 \\
\hline 11 & BW11 & 2.8 & 1 & 51 & BW51 & 6.9 & 4 & 91 & BMW30 & 1.15 & 0.4 \\
\hline 12 & BW12 & 4.15 & 1.6 & 52 & BW52 & 2.4 & 1.35 & 92 & BMW31 & 1.9 & 1.1 \\
\hline 13 & BW13 & 1.8 & 1.7 & 53 & BW53 & 9 & 7 & 93 & BMW32 & 1.55 & 1.1 \\
\hline 14 & BW14 & 2.9 & 1.9 & 54 & BW54 & 7.05 & 6.4 & 94 & BMW33 & 1.6 & 1.2 \\
\hline 15 & BW15 & 5.7 & 2.2 & 55 & BW55 & 3 & 0.82 & 95 & BMW34 & 1.4 & 0.4 \\
\hline 16 & BW16 & 7.7 & 2.1 & 56 & BW56 & 1.3 & 1.1 & 96 & BMW35 & 3.9 & 4.1 \\
\hline 17 & BW17 & 5.8 & 5.7 & 57 & BW57 & 5 & 6 & 97 & BMW36 & 6.3 & 5.3 \\
\hline 18 & BW18 & 2.5 & 2.5 & 58 & BW58 & 3.15 & 2.1 & 98 & BMW37 & 4 & 0.26 \\
\hline 19 & BW19 & 1 & 0.8 & 59 & BW59 & 2.3 & 1.5 & 99 & BMW38 & 4.2 & 1.3 \\
\hline 20 & BW20 & 4.5 & 1.7 & 60 & BW60 & 3.34 & 2 & 100 & BMW39 & 3.65 & 3.4 \\
\hline 21 & BW21 & 2.15 & 1.2 & 61 & BW61 & 5.6 & 3 & 101 & BMW40 & NA & NA \\
\hline 22 & BW22 & 2.65 & 2.5 & 62 & BMW1 & 0.9 & 0.5 & 102 & BMW41 & 4.8 & 2 \\
\hline 23 & BW23 & 5.8 & 3.3 & 63 & BMW2 & 3.6 & 0.9 & 103 & BMW42 & 3.65 & 3.7 \\
\hline 24 & BW24 & 4.75 & 1.8 & 64 & BMW3 & 4 & 1.3 & 104 & BMW43 & 1.6 & 1 \\
\hline 25 & BW25 & 5.1 & 4.6 & 65 & BMW4 & 5.8 & 1.65 & 105 & BMW44 & 4.7 & 2.4 \\
\hline 26 & BW26 & 4.1 & 0.6 & 66 & BMW5 & 3.1 & 1.5 & 106 & BMW45 & 4 & 0.75 \\
\hline 27 & BW27 & 4.9 & 1.6 & 67 & BMW6 & 6.1 & 1.4 & 107 & BMW46 & 5.1 & 3.8 \\
\hline 28 & BW28 & 3.6 & 2.4 & 68 & BMW7 & 3.5 & 2.3 & 108 & BMW47 & 4.5 & 2.5 \\
\hline 29 & BW29 & 1.8 & 1.8 & 69 & BMW8 & 3.6 & 2.4 & 109 & BMW48 & 7 & 3.1 \\
\hline 30 & BW30 & 3.1 & 2.3 & 70 & BMW9 & 1.8 & 1.1 & 110 & BMW49 & 2.85 & 2.6 \\
\hline 31 & BW31 & 4.4 & 4.8 & 71 & BMW10 & 5.3 & NA & 111 & BMW50 & 5.7 & 4.2 \\
\hline 32 & BW32 & 5.5 & 5.65 & 72 & BMW11 & 3.2 & 1.1 & 112 & BMW51 & 3 & 2.6 \\
\hline 33 & BW33 & 2.7 & 0.63 & 73 & BMW12 & 1.8 & 1.3 & 113 & BMW52 & 3.75 & 1 \\
\hline 34 & BW34 & 7 & 5 & 74 & BMW13 & 3.3 & 2.4 & 114 & BMW53 & 5 & 4.2 \\
\hline 35 & BW35 & 2.2 & 1.3 & 75 & BMW14 & 4.8 & 4.2 & 115 & BMW54 & 3.7 & 1.3 \\
\hline 36 & BW36 & 7 & 6.9 & 76 & BMW15 & NA & 1.9 & 116 & BMW55 & 4.5 & 1.5 \\
\hline 37 & BW37 & 2.6 & 0.95 & 77 & BMW16 & 3 & 3.1 & 117 & BMW56 & 3.55 & 1 \\
\hline 38 & BW38 & 7.5 & 7.11 & 78 & BMW17 & 4.25 & 1.4 & 118 & BMW57 & 12.5 & 4 \\
\hline 39 & BW39 & 7.2 & 6.75 & 79 & BMW18 & 1.45 & 1.5 & 119 & BMW58 & 1.9 & 0.3 \\
\hline 40 & BW40 & 1.5 & 0.9 & 80 & BMW19 & 4.1 & 2.2 & 120 & BMW59 & 3 & 2.6 \\
\hline
\end{tabular}


Table 1: Data of water level collected from the field (Contd.)

\begin{tabular}{|c|c|c|c|c|c|c|c|c|c|c|c|}
\hline $\begin{array}{l}\text { S. } \\
\text { No }\end{array}$ & Well ID & $\begin{array}{c}\text { Shallow } \\
\text { ground } \\
\text { water level } \\
\text { of dry } \\
\text { season (LD) }\end{array}$ & $\begin{array}{c}\text { Shallow } \\
\text { ground } \\
\text { Water level } \\
\text { of wet } \\
\text { season }(L W)\end{array}$ & $\begin{array}{l}\text { S. } \\
\text { No }\end{array}$ & Well ID & $\begin{array}{c}\text { Shallow } \\
\text { ground water } \\
\text { level } \\
\text { of dry season } \\
\text { (LD) }\end{array}$ & $\begin{array}{c}\text { Shallow } \\
\text { ground } \\
\text { Water level } \\
\text { of wet } \\
\text { season }(L W)\end{array}$ & $\begin{array}{c}\text { S. } \\
\text { No }\end{array}$ & Well ID & $\begin{array}{c}\text { Shallow } \\
\text { ground } \\
\text { water level } \\
\text { of dry } \\
\text { season (LD) }\end{array}$ & $\begin{array}{c}\text { Shallow } \\
\text { ground } \\
\text { Water level } \\
\text { of wet } \\
\text { season }(\text { LW) }\end{array}$ \\
\hline 121 & BMW60 & 11.2 & 9.5 & 161 & MW31 & 6.4 & 4.9 & 201 & MW71 & 5.5 & 5.6 \\
\hline 122 & BMW61 & 1.6 & 1.1 & 162 & MW32 & 3.55 & 0.6 & 202 & MW72 & 10.7 & 8.9 \\
\hline 123 & BMW62 & 6.7 & 1.5 & 163 & MW33 & 5.74 & 5.2 & 203 & DW1 & 2.35 & 2.4 \\
\hline 124 & BMW63 & 9 & 9 & 164 & MW34 & 5.6 & 5.1 & 204 & DW2 & 2.5 & 2.1 \\
\hline 125 & BMW64 & 7.9 & 7.9 & 165 & MW35 & 8.14 & 8.2 & 205 & DW3 & 2.4 & 1.8 \\
\hline 126 & BMW65 & 1.6 & 1.6 & 166 & MW36 & 3.8 & 2.15 & 206 & DW4 & 1.6 & 0.1 \\
\hline 127 & BMW66 & 2.6 & 2.6 & 167 & MW37 & 3.85 & 0.6 & 207 & DW5 & 3.3 & 2.1 \\
\hline 128 & BMW67 & 2.4 & 2.4 & 168 & MW38 & 4.36 & 3.85 & 208 & DW6 & 2.2 & 1.9 \\
\hline 129 & BMW68 & 1.45 & 1.45 & 169 & MW39 & 7.07 & 5.27 & 209 & DW7 & 3.25 & 1.2 \\
\hline 130 & BMW69 & 6.1 & 6.1 & 170 & MW40 & 5.43 & 5.51 & 210 & DW8 & 2.55 & 1.6 \\
\hline 131 & MW1 & 5.55 & 5 & 171 & MW41 & 5.4 & 2.65 & 211 & DW9 & 3.3 & 1.1 \\
\hline 132 & MW2 & 1.1 & 0.1 & 172 & MW42 & 3.27 & 0.6 & 212 & DW10 & 5.1 & 0.4 \\
\hline 133 & MW3 & 4.8 & 3 & 173 & MW43 & 4.34 & 2.7 & 213 & DW11 & 2.1 & 2.2 \\
\hline 134 & MW4 & 2.85 & 1.7 & 174 & MW44 & 9.1 & 8.65 & 214 & DW12 & 3.3 & 2.5 \\
\hline 135 & MW5 & 2.5 & 1.8 & 175 & MW45 & 4.65 & 4.4 & 215 & DW13 & 1.7 & 0.8 \\
\hline 136 & MW6 & 5.7 & 2 & 176 & MW46 & 4.62 & 2.34 & 216 & DW14 & 2.6 & 2 \\
\hline 137 & MW7 & 1.15 & 1.8 & 177 & MW47 & 0.65 & 0.13 & 217 & DW15 & 2 & 0.9 \\
\hline 138 & MW8 & 3.6 & 1.6 & 178 & MW48 & 1.05 & 0.2 & 218 & DW16 & 1.8 & 1.3 \\
\hline 139 & MW9 & 3.1 & 1.9 & 179 & MW49 & 3.09 & 2.04 & 219 & DW17 & 1.7 & 1.25 \\
\hline 140 & MW10 & 5 & 1.1 & 180 & MW50 & 6.45 & 5.12 & 220 & DW18 & 3.8 & 2.5 \\
\hline 141 & MW11 & 4.5 & 3.4 & 181 & MW51 & 9.25 & 9 & 221 & DW19 & 3.7 & 3 \\
\hline 142 & MW12 & 1.8 & 1.2 & 182 & MW52 & 5.45 & 5.25 & 222 & DW20 & 3.2 & 2.5 \\
\hline 143 & MW13 & 3 & 1.75 & 183 & MW53 & 4.42 & 4.02 & 223 & DW21 & 3.3 & 1.7 \\
\hline 144 & MW14 & 4.5 & 4.8 & 184 & MW54 & 3.83 & 2.98 & 224 & DW22 & 3.4 & 2 \\
\hline 145 & MW15 & 3.7 & NA & 185 & MW55 & 5.93 & 5.6 & 225 & DW23 & 11.8 & 2.8 \\
\hline 146 & MW16 & 2.8 & 1.5 & 186 & MW56 & 6.2 & 5.75 & 226 & DW24 & 4.7 & 3.1 \\
\hline 147 & MW17 & 1.8 & 2 & 187 & MW57 & 7.76 & 7.7 & 227 & DW25 & 2 & 1.8 \\
\hline 148 & MW18 & 2.3 & 0.5 & 188 & MW58 & 7.1 & 2.85 & 228 & DW26 & 1.1 & 1.8 \\
\hline 149 & MW19 & 2.4 & 1.8 & 189 & MW59 & 1 & 0.75 & 229 & DW27 & 2.5 & 0.9 \\
\hline 150 & MW20 & 2 & 2.2 & 190 & MW60 & 2.8 & 1.42 & 230 & DW28 & 2.3 & 1.8 \\
\hline 151 & MW21 & 5 & 4.7 & 191 & MW61 & 5.1 & 4.4 & 231 & DW29 & 3.4 & 2.5 \\
\hline 152 & MW22 & 3.1 & 1.7 & 192 & MW62 & 3 & 3.05 & 232 & DW30 & 3.3 & 1.7 \\
\hline 153 & MW23 & 3.75 & 0.3 & 193 & MW63 & 8.2 & 7.2 & 233 & DW31 & 1.9 & 1.2 \\
\hline 154 & MW24 & 3.5 & 2.6 & 194 & MW64 & 8.69 & 7.8 & 234 & DW32 & 5.5 & 4.3 \\
\hline 155 & MW25 & 4.1 & 2.6 & 195 & MW65 & 2.2 & 1.5 & 235 & DW33 & 4.9 & 3.9 \\
\hline 156 & MW26 & 4.3 & 2.7 & 196 & MW66 & 1.7 & 0.7 & 236 & DW34 & 4.5 & 2.2 \\
\hline 157 & MW27 & 0.6 & 0.1 & 197 & MW67 & 9.2 & 9.2 & 237 & DW35 & 2.7 & 1.5 \\
\hline 158 & MW28 & 4.8 & 3.3 & 198 & MW68 & 2.7 & 0.5 & 238 & DW36 & 4.36 & 2.6 \\
\hline 159 & MW29 & 2.5 & 0.3 & 199 & MW69 & 12.4 & 11.7 & 239 & DW37 & 5.75 & 2 \\
\hline 160 & MW30 & 1.3 & 0.6 & 200 & MW70 & 4.9 & 3.5 & & & & \\
\hline
\end{tabular}




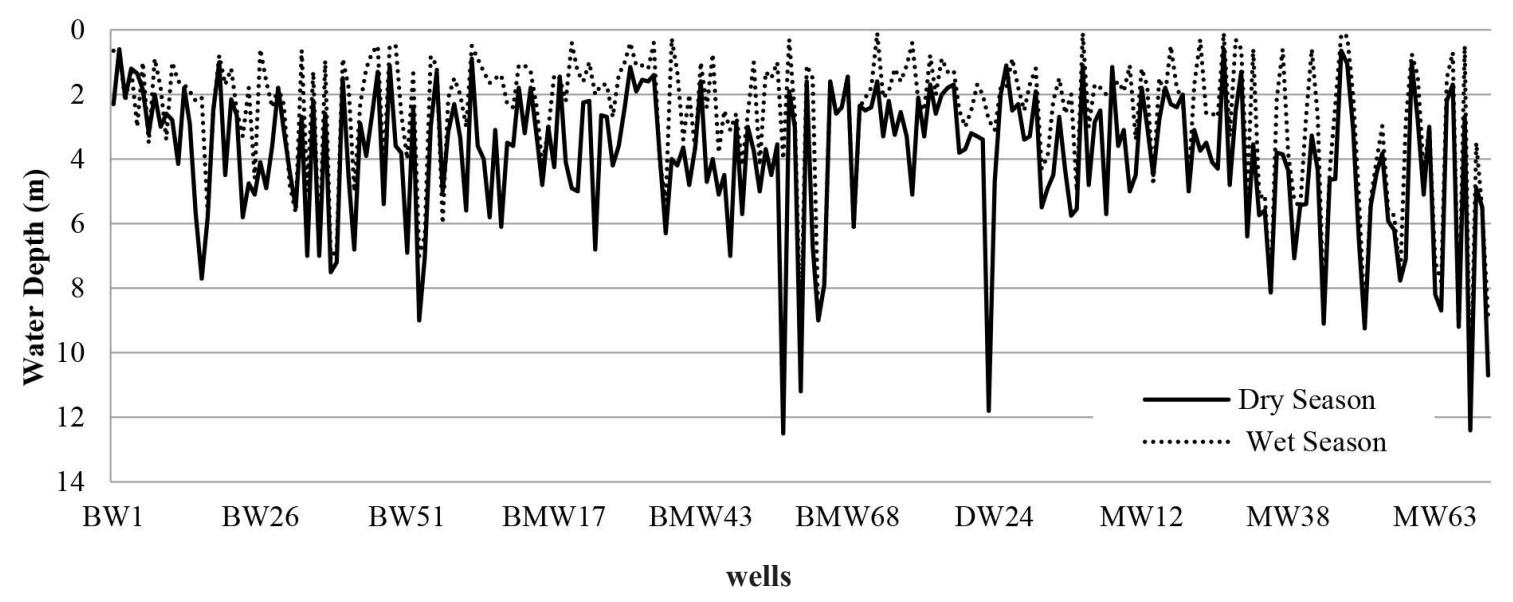

Fig. 5: Seasonal variation on water level of the study area.

Calculation: Increment percentage of water level of each well (I L) is given by:

$$
\mathrm{IL}=[(\mathrm{LD}-\mathrm{LW}) / \mathrm{LD}] .100 \%
$$

Average increment of water level is obtained by:

$$
\mathrm{ILavg}=(\mathrm{SUM} \text { IL }) / \mathrm{n}
$$

For the calculation of the increment of percentage of water level equation (1) was used where for each well the water level of wet season was deducted from dry season and divided by water level of dry season to get the increased percentage of water level in wet season. The value obtained from each well were added and divided by total number of wells to get average increment of water level. From the calculation it was found that the groundwater level increased by an average of $34.68 \%$ ( $n=$ 235) as compared to that in dry season (Fig. 5). Wells whose water level could not be obtained were not taken in the calculation.

The wells data collected from the field were overlaid in Environmental and Engineering geological map of the Kathmandu Valley (Fig. 2), 103 wells lied in Recent Flood Plain, 70 wells lied in the Gokarna Formation and 54 wells lied in the Kalimati Formation. Only two wells lied in the Chapagaon Formation, Kulikhani Formation, Lukundol Formation and the Tokha Formation. Comparing the data based on the geology, the wells which lied in the Recent Flood Plain showed increment of water level in average of $38.16 \%$. The wells of the Kalimati Formation showed increment of water level of an average of $32.92 \%$ and the least increment of an average of $31.22 \%$ by the wells of Gokarna Formation. The reason behind high percentage of increment in Recent Flood Plain is this formation is composed of sands and gravel deposits up to boulder size along with clay, sand and fine gravel making it highly potential zone of groundwater with periodic change in groundwater level. Also wells which lies in Recent Flood Plain are near to the river corridor which easily recharge the wells increasing the water level. While the Gokarna Formation is composed of light to brownish gray, thinly laminated and poorly graded silty sand with intercalation of clay of variable thickness causing less recharge of groundwater and less increment of water level. The wells lying in the Chapagoan Formation, Kulikhani Formation, Lukundol Formation and the Tokha Formation was not taken because number of wells were very less for finding out the average result.

The flow pattern of groundwater from the study shows that the flow of shallow groundwater is towards the major rivers of the particular river watershed. Since the flow is towards the river of the particular watershed, seepage flow and piping erosion are likely along the river bank slopes as shown in some photographs (Figs. 6, 7, 8 and 9). These figures show that there are presence of seepage flow and piping erosion along the river bank slopes.

\section{CONCLUSIONS}

From the study it is concluded that the average increment in the water level of study area is $34.68 \%$ from dry season to wet season. The wells which lied in the Recent Flood Plain showed highest percentage $(38.16 \%)$ of increase in water level while the wells lying in the Gokarna Formation showed least increment of water level $(31.22 \%)$. The increment in the groundwater level in wet season suggests recharge of groundwater. However, the average increment percentage of water level is very low, thus it is highly recommended to find a convenient technique for maximizing the shallow groundwater recharge, such that the water can be used in systematic way in dry season. The flow pattern of the shallow groundwater level of the study area is towards the river of that particular watershed and ultimately towards the Bagmati River at the south west part 


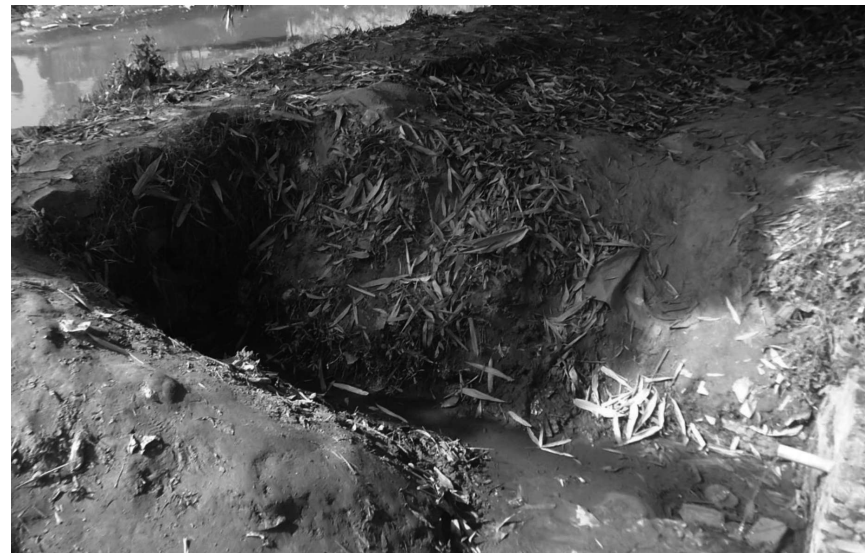

Fig. 6: Seepage water collection at right bank of the Bagmati river near Baneshwor

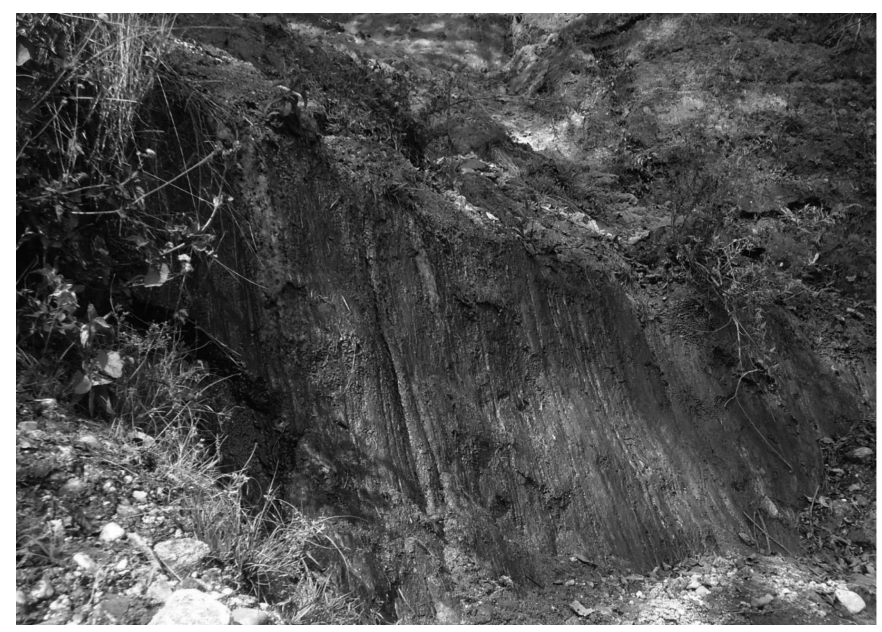

Fig. 8: Piping erosion observed at left bank of the Bishnumati River near Dhapasi

of the study area. The flow of water towards river has caused the seepage and piping erosion at the river banks.

\section{ACKNOWLEDGEMENT}

This is in part the outcome of the first author's M. Sc. dissertation. Authors are thankful to the Central Department of Geology for providing facilities.

\section{REFERENCES}

Department of Mines and Geology (DMG), 1998, Engineering and Environmental Geological Map of the Kathmandu Valley. Published by DMG in cooperation of BGR, Germany.

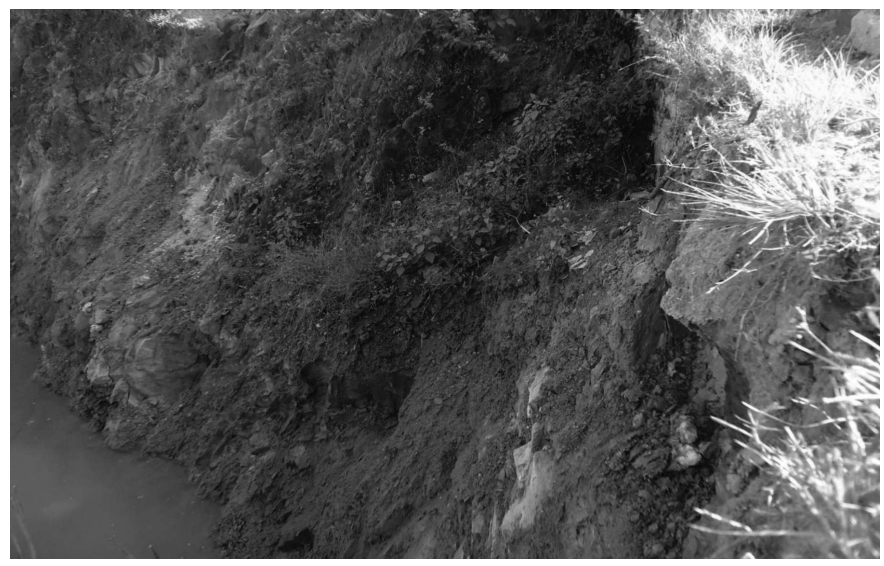

Fig. 7: Seepage water collection at right bank of the Bagmati river near Baneshwor



Fig. 9: Seepage and erosion observed at left bank of the Dhobi Khola near Budhanilkantha

Dixit, A. and Upadhya, M., 2005, Augmenting groundwater in Kathmandu Valley: Challenges and possibilities, Nepal Water Conservation Foundation, Kathmandu, Nepal, 42p.

Japam International Co-operation Agency (JICA), 1990, Groundwater Management Project in Kathmandu Valley. Final Report (Unpublished), 631p.

Sharma, P. N. and Singh, O. R., 1966. Groundwater Resources of Kathmandu Valley. Supplementary Report. Available: http:/www.gwrdb.gov.np/publications.php

Qin, Y.D. and Li, B.G., 1998. Estimating of groundwater level distribution by disjunctive kriging. Journal of Hydrualic Engineering, v. 8, pp 28-33. 